\title{
Analisa Perubahan Garis Pantai di Wilayah Pantai Antara Muara Batang Air Dingin dan Muara Batang Anai Provinsi Sumatera Barat
}

\author{
Boy Setiawan $^{1 *}$, Junaidi², Ahmad Junaidi ${ }^{3}$ \\ ${ }^{1}$ Magister Teknik Sipil Universitas Andalas \\ ${ }^{2,3}$ Teknik Sipil Universitas Andalas \\ *Correspondence email: boysetiawan26@yahoo.com, ${ }^{2}$ junaidi.joe@gmail.com, ${ }^{3}$ ahmad_junaidi@eng.unand.ac.id
}

\begin{abstract}
Abstrak. Garis pantai antara Muara Batang Air Dingin dengan Muara Batang Anai terletak sebagian di kota padang dan sebagian di Kabupaten Padang Pariaman, Propinsi Sumatera Barat. Sebelum tahun 2012 terjadi abrasi, hempasan ombak pada saat terjadi badai, dapat mencapai rumah-rumah penduduk. Pada tahun 2012, Balai Wilayah Sungai Sumatera V (BWSS V) dan Dinas Pengelolaan Sumber Daya Air (PSDA) Propinsi Sumatera Barat membangun groin untuk menanggulangi abrasi. Untuk mengetahui dampak dibangun groin ini, penulis tertarik untuk meneliti dan menganalisa perubahan garis pantai di wilayah pantai antara muara Batang Air Dingin dan muara Batang Anai. Tujuan utama dari penelitian ini adalah mengetahui posisi akresi dan abrasi sepanjang garis pantai di tempat penelitian serta membuat simulasi arah gelombang sehingga dapat diketahui arah laju partikel (sedimen) akibat adanya bangunan pengaman pantai. Untuk membuat simulasi perubahan garis pantai, penulis menggunakan software GENESIS. Dari penelitian ini diketahui bahwa pada lokasi yang telah dibangun groin, terjadi akresi di sepanjang lokasi pantai tempat penelitian. Pertambahan garis pantai mencapai $25 \mathrm{~m}$ dan laju akresi mencapai 4,2 meter/tahun. Pada daerah yang belum dibangun groin, terjadi abrasi akibat pengaruh berkurangnya pasokan sedimen karena telah ditangkap oleh groin yang berada pada sisi kirinya. Laju abrasi pertahun adalah $1,2 \mathrm{~m} /$ thn yang berada di lokasi pasie jambak Kota Padang. Berdasarkan simulasi Genesis 10 tahun kedepan dari tahun 2017. Terjadi pergerakan sedimen yang bergerak dari kiri kekanan saat pengamat menghadap kelaut. Pemasangan groin yang efektif dalam memajukan garis pantai, namun berdampak negatif pada daerah yang belum dibangun groin seperti mundurnya garis pantai akibat berkurangnya pasokan sedimen.
\end{abstract}

Kata Kunci : akresi, abrasi, groin, GENESIS

\section{PENDAHULUAN}

Kota Padang mempunyai garis pantai $\pm 18 \mathrm{KM}$ atau hampir 5\% dari panjang total garis pantai Sumatera Barat. Gelombang yang sampai tidak sebesar bagian selatan pulau jawa. Namun karena topografi pantai Padang yang curam dan berpasir, menyebabkan terjadinya abrasi. Sejarah kemunduran pantai Padang dapat dilihat pada gedung Pancasila yang dulu ada di jalan Samudera yang berdekatan pada jalan Veteran. Pada tahun 1938 masih saat penjajahan Belanda, jarak antara garis pantai Padang dengan bangunan tersebut adalah $40 \mathrm{~m}$. Pada tahun 1963 - 1964 terjadi badai besar yang mengakibatkan abrasi

Kemudian dibangunlah revetment, namun konstruksi tersebut dibuat bukan untuk menangkap sedimen. Sehingga langsung terkena oleh hantaman ombak, akibatnya konstruksi tersebut mengalami kerusakan dan juga menghancurkan Gedung Pancasila, sesuai gambar kronologis di bawah ini:

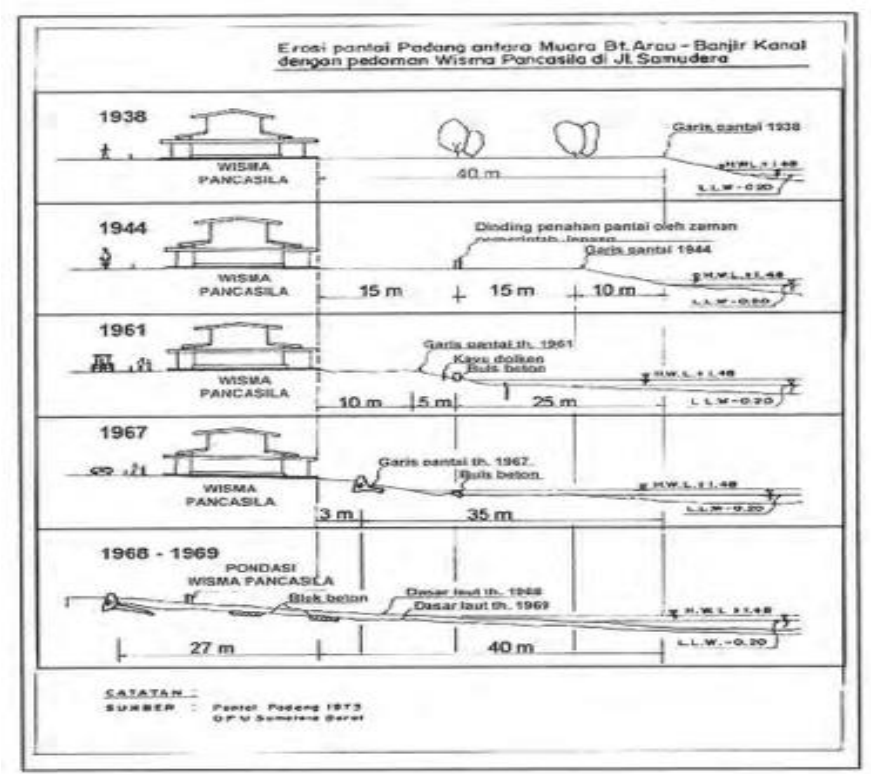

Gambar 1. Kemunduran Pantai Padang (1938-1969) (Istijono, 2013) 
Pada tahun 1969, jarak gedung pancasila dari garis pantai sejauh $67 \mathrm{~m}$ dan itu mampu dicapai oleh gelombang laut pantai Padang (Dalrini, 2016). Pada penelitan ini wilayah yang menjadi kajian adalah Perairan Pantai antara muara Batang Air Dingin kota Padang dan muara Batang Anai di kabupaten Padang Pariaman Propinsi Sumatera Barat. Pantai di antara muara Batang Air dingin dan muara Batang Anai secara geografis terletak antara $0^{\circ} 57^{\prime} 55^{\prime \prime}$ $1^{\circ} 0$ ' 34" LS dan $100^{\circ} 20^{\prime} 24^{\prime \prime}-100^{\circ} 21^{\prime}$ 53" BT . Lokasi penelitian di pulau Sumatera dapat dilihat pada gambar 2. di bawah ini:

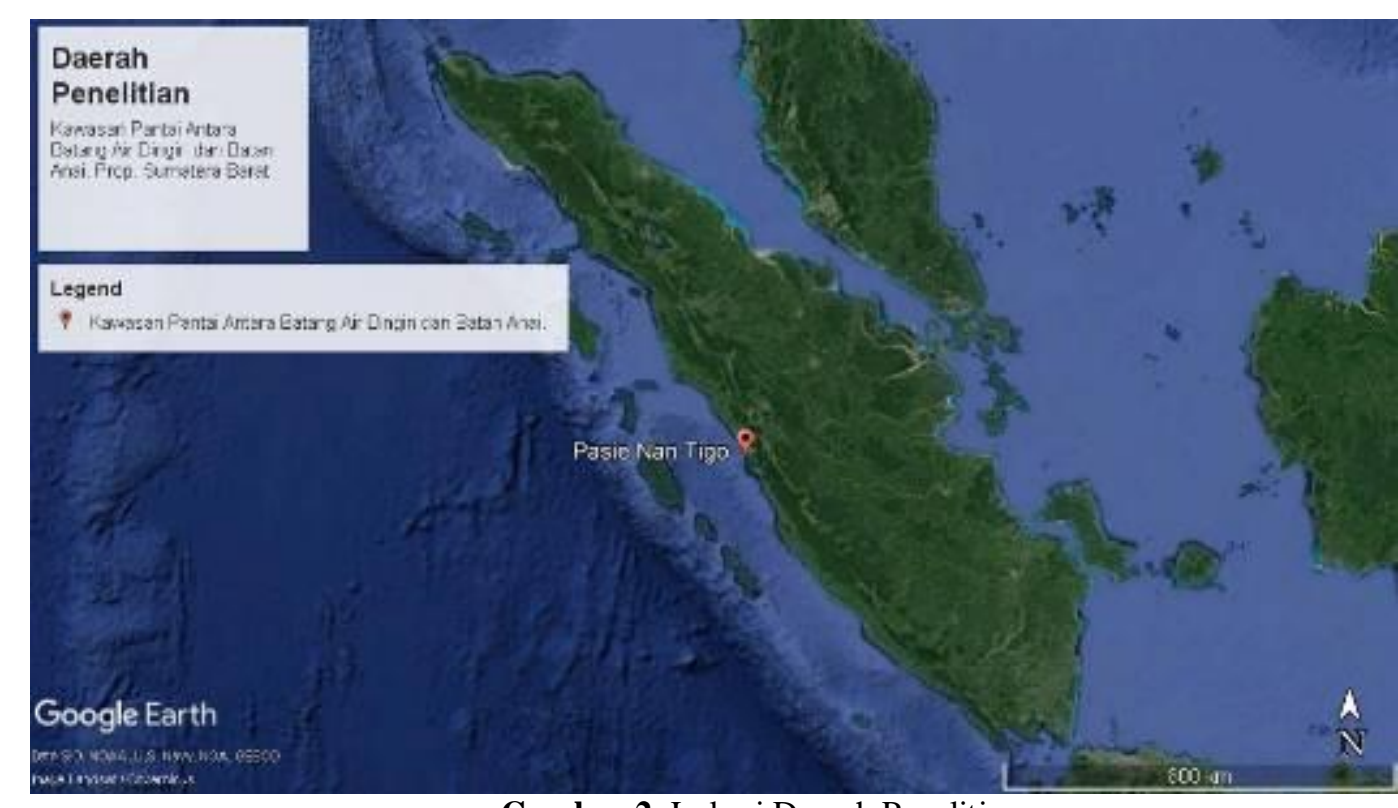

Gambar 2. Lokasi Daerah Penelitian

Pantai antara muara Batang Air Dingin dan muara Batang Anai merupakan perairan yang terletak kurang lebih $11 \mathrm{Km}$ dari pusat Kota Padang tepatnya di Kecamatan Koto Tangah Kelurahan Pasie Nan Tigo Provinsi Sumatera Barat. Pesisir Pantai antara muara Batang Air Dingin dan muara Batang Anai membentuk pantai lurus (long beach) dengan panjang pantai kurang lebih $7 \mathrm{~km}$. Sedimen pantai yang menyusun kawasan pantai ini sebagian besar terdiri dari pasir pantai terutama terdapat di sekitar muara-muara sungai besar yang memperlihatkan adanya proses sedimentasi aktif. Abrasi yang terjadi di pantai ini telah mencapai rumah-rumah penduduk yang berada di bibir pantai. Pada akhir tahun 2012, Kementrian PUPR dan dinas PSDA Propinsi Sumatera Barat bekerja sama membangun sejumlah groin untuk menanggulangi kemunduran garis pantai ini.

Tujuan dari penelitian ini adalah untuk mengetahui sejauh mana efektifias dari pembangunan groin ini dan mengetahui perubahan garis pantai berupa jarak maju atau mundurnya garis pantai yang terjadi setelah dibangun groin sejak tahun 2012 hingga tahun 2018, laju perubahan garis pantai, serta dampak dibangunnya groin pada daerah yang belum dipasang groin. Penelitian ini mengkaji perubahan garis pantai yang terjadi akibat gelombang pantai yang datang dari arah laut dan tidak termasuk pengaruh muara sungai disebabkan gelombang yang datang arah laut berpengaruh besar dari pada muara sungai.

Pada penelitian ini terdapat beberapa literatur perubahan garis pantai seperti pada tahun 2013 Suhaemi dan Fitri Riandini melakukan penelitan tentang Dinamika Garis Pantai Sanur Bali Akibat Adanya Struktur Sejajar Pantai. Hasil simulasi menunjukkan bahwa rata-rata penambahan garis pantai selama periode 2005-2007 mencapai 1,49 m, sedangkan lebar maksimum penambahan garis pantai berdasarkan hasil simulasi mencapai 11,86 m. Analisis kesalahan terhadap perbandingan simulasi dan pengukuran menunjukkan tingkat kesalahan yang relatif kecil, dengan persentase kesalahan berkisar antara $1,1-2,6 \%$ atau rata-rata perbedaan mencapai $0,6 \mathrm{~m}$. Berdasarkan hasil analisis geometri breakwater, tombolo tidak akan terbentuk di pantai Sanur karena rasio B/S adalah 0,90 sementara rasio B/S mensyaratkan tombolo terbentuk jika rasio $\mathrm{B} / \mathrm{S}$ adalah lebih besar 0,97 . Hasil simulasi memperlihatkan bahwa model telah cukup baik menggambarkan perubahan garis pantai (Suhaemi dan Fitri Riandini , 2013).

Pada tahun 2016 M. Imran melakukan penelitan tentang pemodelan bentuk transportasi sendimen menggunakan mike 21 contohnya pada pantai lampu satu kab. Merauke di Papua. Tujuan penelitian ini yaitu guna mengetahui keadaan dan situasi hidrodinamika dan pola Trasnsportasi sedimen di pantai lampu satu. Data-data pada penelitian ini menggunakan software DHI Mike 21 yang dapat mendeskripsikan kondisi laut dan pesisir yang berpengaruh terhadap pola transport sedimen adalah gelombang dan arus. Metode yang dipakai yaitu metode kuantitatif yang terdiri dari metode ilmiah, dan berbagai metoda lainnya. Data kondisi di lapangan yang diukur adalah data pasut, arus laut, peta batimetri, sedimentasi dan data angin. Penelitian ini menghasilkan pemodelan sediment transport yang berasal dari 
Sungai Maron menuju daerah pantai Lampu satu, daerah yang dapat berpotensi terjadi sedimentasi paling besar adalah lokasi $50 \mathrm{~m}$ dari garis pantai lampu satu yaitu mulai dari $1050 \mathrm{~m}^{3} /$ th hingga1200 $\mathrm{m}^{3} / \mathrm{th}$ (Imran, 2016).

\section{METODE}

Terdapat dua Metoda yang digunakan untuk mengetahui perubahan garis pantai pada lokasi penelitian ini, yaitu metoda tumpang susun dengan menggunakan peta citra satelit yang bersumber dari google earth dan metoda simulasi dengan memakai software GENESIS. Untuk metoda tumpang susun dengan citra satelit dapat menghasilkan laju perubahan garis pantai dan jarak perubahan garis pantai, sedangkan metoda simulasi GENESIS menghasilkan arah gelombang sedimentasi dan bentuk perubahan garis pantai setelah dibangun groin. Berikut penjelasan dari masingmasing metode.

Untuk Metoda Tumpang susun, data yang dibutuhkan adalah peta lokasi penelitan tahun 2007, peta citra satelit pada tahun 2012 (saat dibangun groin) dan peta citra satelit pada tahun 2018 (sudah ada groin). Langkah-langkah yang dilakukan adalah digitasi ketiga peta cita satelit tersebut untuk mendapatkan informasi posisi garis pantai dan tumpang susun peta citra satelit (overlay) untuk mendapatkan informasi jarak perubahan garis pantai dan laju perubahan garis pantai.

Simulasi perubahan garis pantai menggunakan software GENESIS bertujuan untuk mengetahui pengaruh perubahan garis pantai yang akan terjadi pada saat sebelum dibangun groin dan sesudah dibangun groin. Langkahlangkah simulasi perubahan garis pantai menggunakan software GENESIS adalah sebagai berikut:

Digitasi Garis pantai dan peta batimetri

Garis pantai yang gunakan adalah hasil digitasi koordinat peta tahun 2007 (belum ada groin), tahun 2012 (dibangun groin) dan 2018 (sudah ada groin) yang bersumber dari google earth. Peta batimetri menggunakan data dari General Bathymetric Chart of the Oceans (GEBCO) tahun 2014 dengan resolusi 30 arc second, kemudian ekstrak koordinat menggunakan software global mapper dengan interval $10 \mathrm{~m}$. Peta Batimetri daerah penelitian dapat dilihat pada gambar 3 berikut.

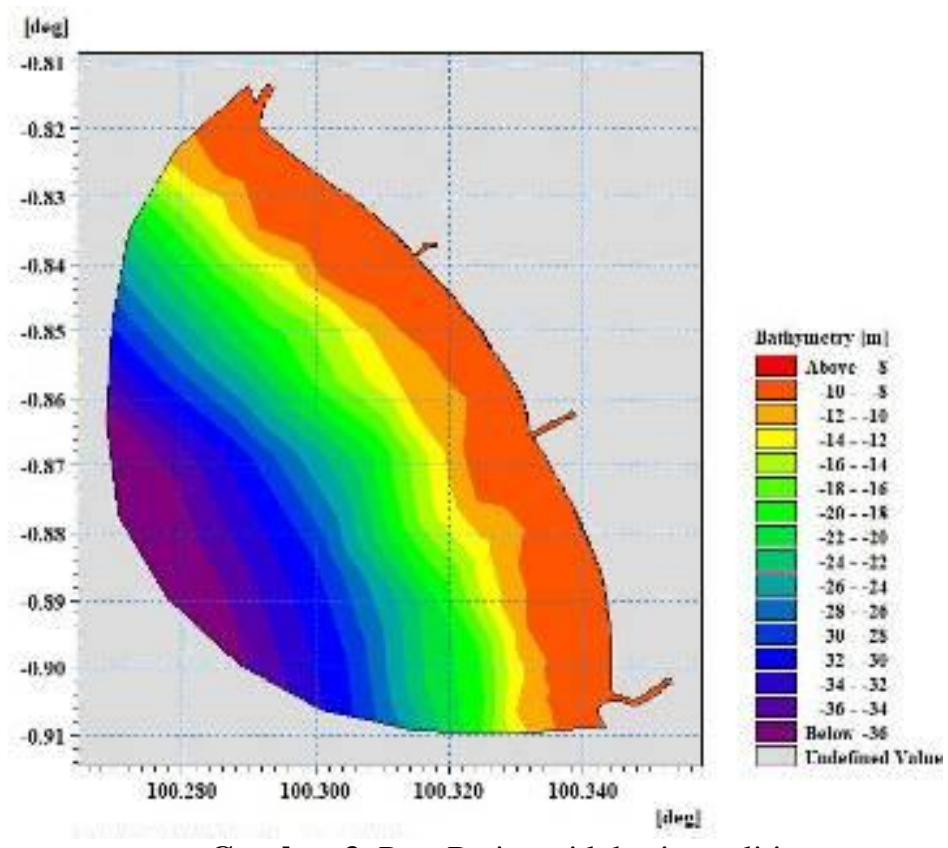

Gambar 3. Peta Batimetri lokasi penelitian

Dari peta batimetri di atas, pantai antara muara Batang Air Dingin dan muara Batang Anai memiliki kedalaman perairan yang bervariasi, tergantung posisi. Untuk bagian tepi pantai kedalaman nya berkisar antara $8 \mathrm{~m}-10 \mathrm{~m}$.

\section{Data Sedimen $\left(D_{50}\right)$}

Data butiran sedimen diambil secara langsung di lapangan. Pengujian sampel sedimen dilakukan di laboratorium dengan standar prosedur ASTM 422-C3. Hasilnya didapatkan grafik analisa saringan untuk mendapatkan nilai D50 dalam satuan mili meter (mm).

\section{Hindcasting Gelombang}

Hindcasting gelombang bertujuan untuk menghitung dan meramalkan karakteristik gelombang yaitu tinggi $(\mathrm{H})$, periode $(\mathrm{T})$ dan arah gelombang. Dalam hindcasting gelombang data yang digunakan adalah data angin sepuluh tahun 
Boy Setiawan et al, Analisa Perubahan Garis Pantai di Wilayah Pantai Antara Muara Batang Air Dingin dan Muara Batang Anai Provinsi Sumatera Barat

sebelumnya yaitu tahun 2008 - 2017 yang didapatkan dari NOAA Earth System Research Laboratory. Pedoman Perhitungan Hindcasting gelombang bersumber pada Shore Protection Manual (SPM, 1984).

\section{Prakiraan Perubahan Garis Pantai dengan Menggunakan Program GENESIS}

Data-data yang dibutuhkan dalam menjalankan program GENESIS adalah data Shore Line format xyz, data batimetri format xyz yang sudah digabung dengan peta topografi, dan data Time Series Gelombang yang berasal dari Hindcasting gelombang.

\section{HASIL DAN PEMBAHASAN}

Perubahan Garis Pantai dengan metode tumpang susun dari peta citra Satelit Google Earth

Laju perubahan garis pantai menggunakan citra satelit yang bersumber dari Google Earth dengan melakukan overlay garis pantai menggunakan menu history pada toolbar. Garis pantai tahun 2007, 2012 dan 2018 diambil enam lokasi pada titik yang sama setiap tahunnya, kemudian jarak perubahan garis pantai tiap garis diukur dengan menggunakan menu measure pada toolbar. Berikut gambar hasil overlay garis pantai tahun 2007 (belum ada groin), 2012 (mulai dibangun groin), 2018 (sudah ada pengaruh groin).

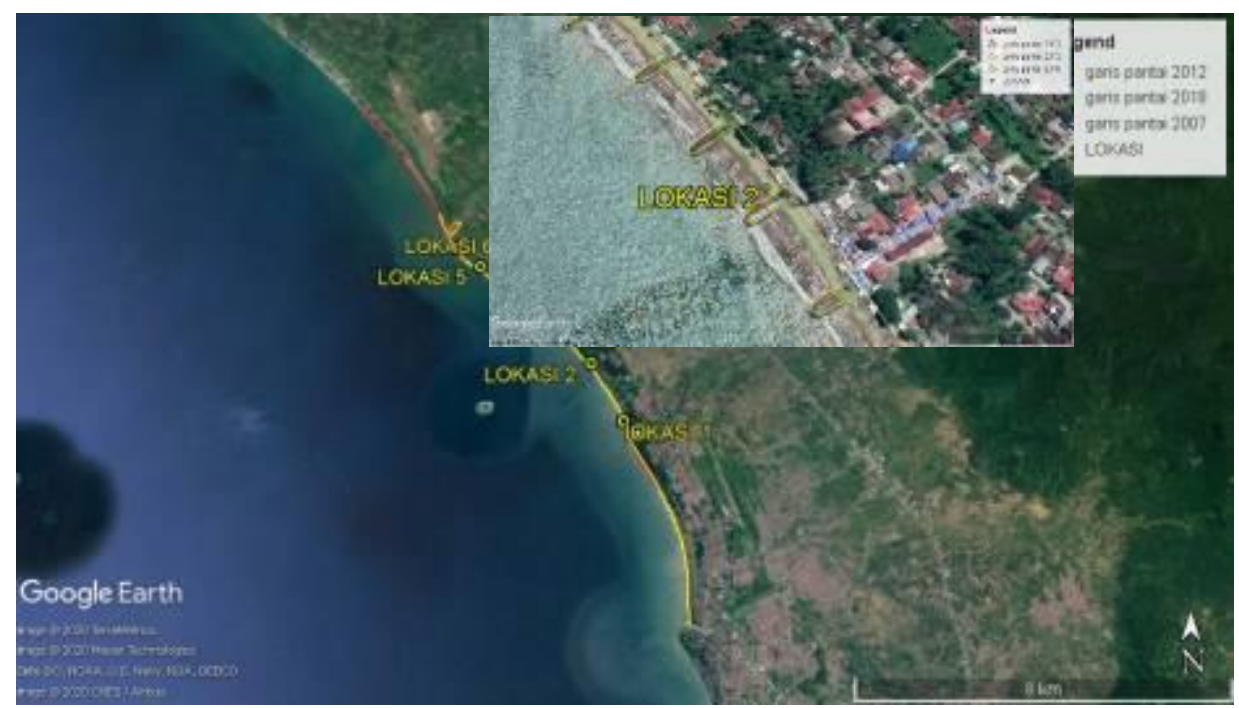

Gambar 4. Overlay garis pantai lokasi penelitian

Tabel di bawah ini merupakan perhitungan hasil overlay laju perubahan garis pantai pertahun seperti yang ada pada tabel sebagai berikut :

Tabel 1. Laju perubahan garis pantai lokasi penelitian

\begin{tabular}{ccccccc}
\hline \multirow{2}{*}{ Lokasi } & \multicolumn{3}{c}{$\begin{array}{c}2007-2012(5 \text { tahun) } \\
\text { Sebelum ada groin }\end{array}$} & \multicolumn{3}{c}{$\begin{array}{c}2012 \text { - 2018 (6 tahun) } \\
\text { Sesudah ada groin }\end{array}$} \\
\cline { 2 - 7 } & Jarak (m) & Status & Laju (m/thn) & Jarak (m) & Status & Laju (m/thn) \\
\hline 1 & 27 & Akresi & 5,4 & 25 & Akresi & 4,2 \\
2 & 24 & Abrasi & 4,8 & 6 & Akresi & 1,0 \\
3 & 7 & Abrasi & 1,4 & 6 & Akresi & 1,0 \\
4 & 17 & Abrasi & 3,4 & 4 & Akresi & 0,7 \\
5 & 2 & Abrasi & 0,4 & 7 & Abrasi & 1,2 \\
6 & 25 & Abrasi & 5,0 & 17 & Akresi & 2,8 \\
\hline
\end{tabular}

Sumber: Data Olahan (2018)

Tabel di atas menunjukkan bahwa sebelum dibangun groin, terjadi abrasi pantai hingga mencapai 27 meter dengan laju $5,4 \mathrm{~m} / \mathrm{thn}$. Sesudah dibangun groin, lokasi tempat terjadi abrasi, mulai terisi kembali dan terjadi penambahan garis pantai hingga $25 \mathrm{~m}$ dengan laju $4,2 \mathrm{~m} / \mathrm{thn}$. Ini berarti Groin yang dibangun mampu menangkap sedimen dan efektif dalam mengembalikan garis pantai. 
Boy Setiawan et al, Analisa Perubahan Garis Pantai di Wilayah Pantai Antara Muara Batang Air Dingin dan Muara Batang Anai Provinsi Sumatera Barat

Arah gelombang yang mempengaruhi garis pantai lokasi penelitian

Data angin yang diperoleh dari NOAA diolah menjadi data gelombang melalui hindcasting yang menghasilkan tinggi gelombang, panjang gelombang dan arah gelombang. Dari ketiga data tersebut dapat dihasilkan mawar gelombang yang berbentuk seperti gambar di bawah ini :

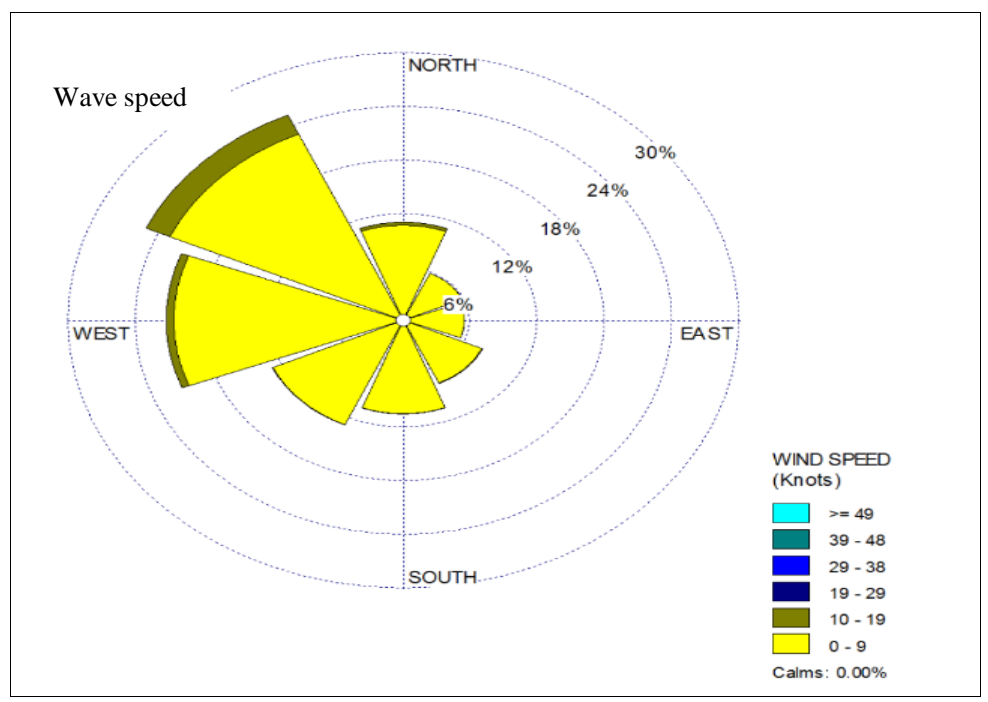

Gambar 5. Wave Rose Lokasi Penelitian

Dari mawar gelombang tersebut dapat diketahui bahwa arah gelombang di pantai lokasi penelitan dominan dari arah Barat Laut menuju tenggara dan dari arah Barat menuju Timur dengan kecepatan berkisar antara dengan kecepatan gelombang 0-9 knot. Sedangkan frekuensi kecepatan gelombang maksimal terbesar dari arah Barah Laut yang berkisar antara $10-19$ knot.

\section{Simulasi Perubahan Garis Pantai dengan menggunakan GENESIS}

Simulasi perubahan garis pantai dengan GENESIS dibagi dalam 2 area, yaitu bagian yang telah dipasang groin, area 1 dan area 2 merupakan daerah yang belum dibangun groin dan merupakan daerah yang berpengaruh langsung akibat adanya groin (gambar 6).

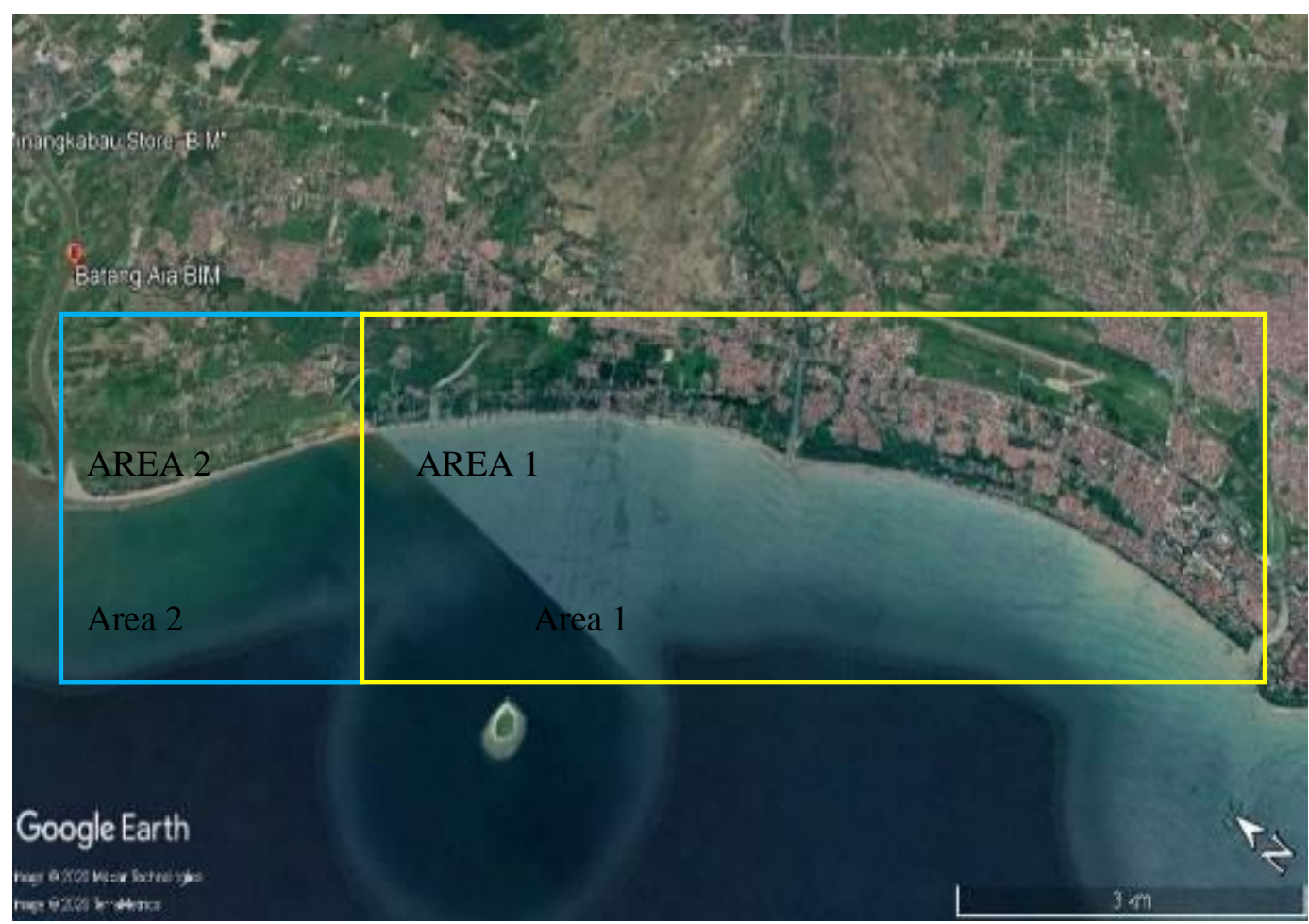

Gambar 6. Pembagian Area Pemodelan dalam GENESIS 
Wilayah yang disimulasikan hanya diambil perwakilan dan tidak sepanjang pantai. Alasannya karena bentuk pantai yang lurus dan tidak ada tanjung sehingga jika digunakan sebagian, tetap akan mewakili perubahan garis pantai yang lain di daerah studi ini. Berikut penjelasan masing-masing area :

\section{Pemodelan garis pantai pada area 1}

Simulasi perubahan garis pantai dengan GENENSIS menggunakan garis pantai tahun 2017 yang bersumber dari Google Earth. Bentuk perubahan garis pantai disimulasikan selama sepuluh tahun kedepan yaitu itu sampai tahun 2027. Simulasi ini bertujuan untuk mengetahui perubahan garis pantai yang disebabkan dibangunnya groin.

Hasil simulasi GENESIS ini memperlihatkan bahwa terjadinya pola perpindahan sedimen yang teratur akibat tertahan oleh groin. Groin tersebut berhasil dan efektif dalam menangkap sedimen, sehingga garis pantai yang semulanya mundur, setelah adanya groin, terjadi akresi atau kembali majunya garis pantai yang terletak di antara groin yang bergerak dari kiri ke kanan seperti yang terlihat pada gambar 7 berikut :

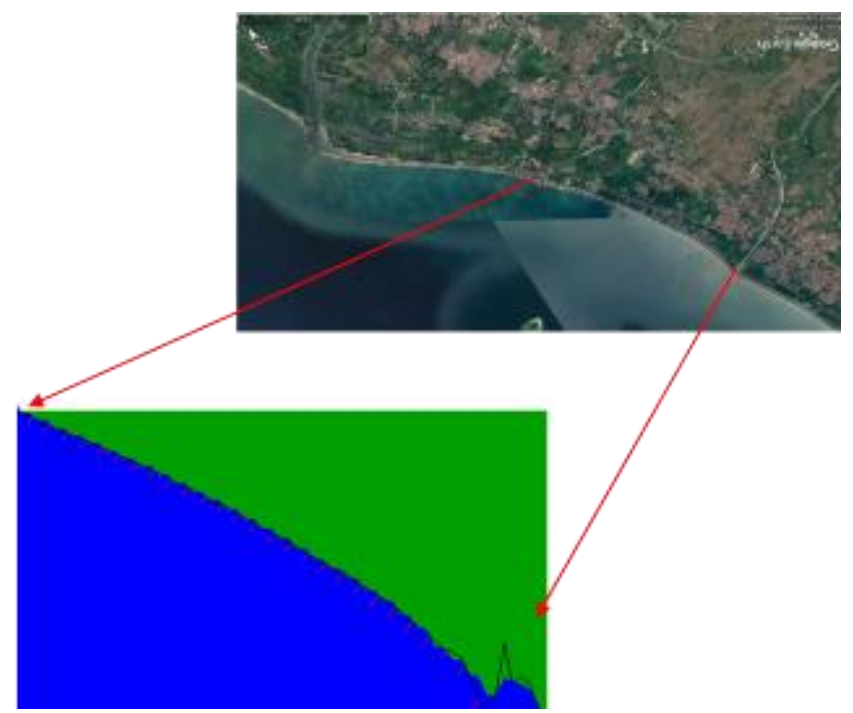

Gambar 7. Bentuk Simulasi perubahan garis pantai akibat adanya groin di lokasi penelitian.

Dari hasil running Genesis pada area 1 yaitu daerah Pasie Sabalah dan Pasie Kandang, Kel. Pasie Nan Tigo, Kota Padang. Arah transpor volume sedimen terbesar berasal dari kiri ke kanan jika kita mengamati menghadap ke arah laut. Pada daerah yang sudah dibangun groin, terisi oleh sedimen. Jika dilihat pada citra satelit yang bersumber dari Google Earth. Berdasarkan hasil simulasi GENESIS, bertambahnya volume sedimen sebesar rata-rata setiap tahun adalah sebesar $8847.1 \mathrm{~m}^{3} /$ tahun. Jumlah volume akresi dan volume abrasi dapat dilihat pada tabel dibawah ini:

Tabel 2. Volume sedimen di lokasi penelitian

\begin{tabular}{cccr}
\hline Tahun & Q Right Transport $(\mathbf{a k r e s i})\left(\mathbf{m}^{\mathbf{3}}\right)$ & Q Left Transport $\left.(\mathbf{a b r a s i}) \mathbf{( m}^{\mathbf{3}}\right)$ & Q nett $_{\left(\mathbf{m}^{\mathbf{3}}\right)}$ \\
\hline $2017-2018$ & 19137 & 15445 & 3692 \\
$2018-2019$ & 20966 & 16236 & 4730 \\
$2019-2020$ & 20829 & 14321 & 6508 \\
$2020-2021$ & 18501 & 10197 & 8304 \\
$2021-2022$ & 20046 & 9760 & 10286 \\
$2022-2023$ & 19159 & 9322 & 9837 \\
$2023-2024$ & 21162 & 9791 & 11371 \\
$2024-2025$ & 20993 & 9232 & 11761 \\
$2025-2026$ & 18433 & 8138 & 10295 \\
$2026-2027$ & 19800 & 8113 & 11687 \\
\multicolumn{2}{c}{ Rata-Rata/thn } \\
\hline
\end{tabular}

Sumber: Data Olahan (2018)

Qnett adalah jumlah volume yang didapatkan dari hasil pengurangan dari Q right (akresi) dan Q left(abrasi). Dari tabel di atas dapat dilihat dari tahun ke tahun jumlah akresi lebih besar dari abrasi, ini menunjukkan juga bahwa pemasangan groin sangat efektif di sepanjang garis pantai lokasi penelitian. Pergerakan sedimen ini jika menghadap ke arah laut, sedimen bergerak dari kiri ke kanan. Hal ini disebabkan karena arah gelombang yang datang dari arah Selatan 


\section{Pemodelan garis pantai pada area 2}

Dari simulasi perubahan garis pantai dengan GENESIS memperlihatkan bahwa daerah yang belum dibangun groin terjadi abrasi sepanjang $445 \mathrm{~m}$. Abrasi ini terjadi sebagai dampak dibangunnya groin seperti yang terlihat pada gambar 8 berikut.

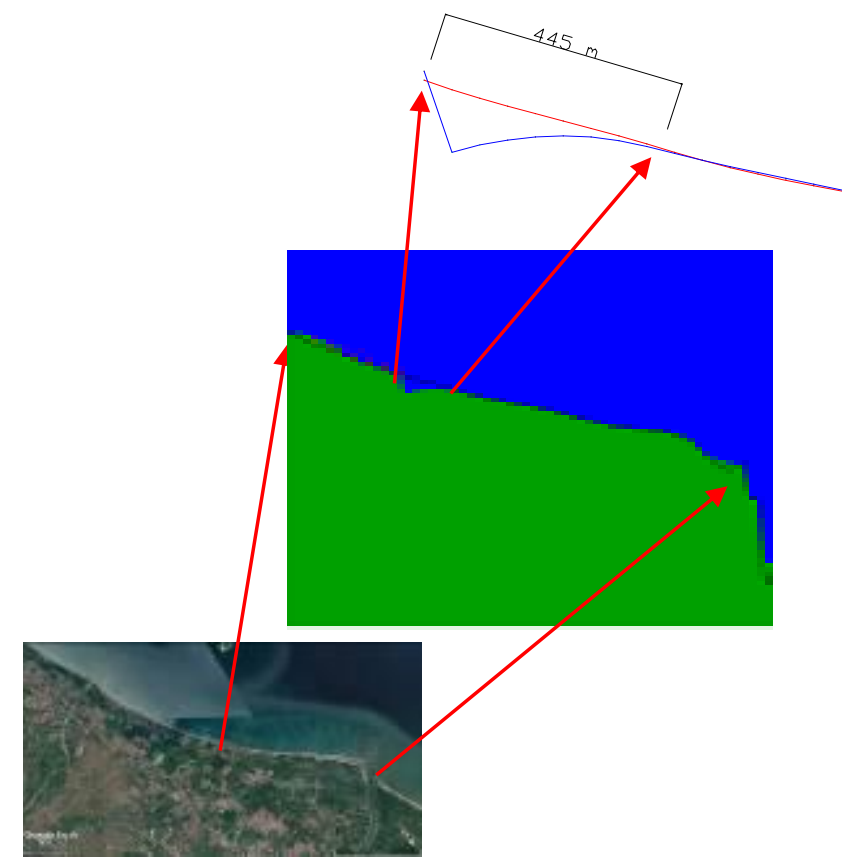

Gambar 8. Simulasi GENESIS area 2

\section{SIMPULAN}

Dari hasil penelitian yang berlokasi di Pantai antara muara Batang Air Dingin dan muara Batang Anai, maka didapatkan beberapa kesimpulan yaitu :

1. Dari hasil pengamatan menggunakan citra satelit yang bersumber dari Google Earth, tahun 2007- 2012 terjadi abrasi dan akresi pada daerah yang belum dibangun groin. Laju Penambahan garis pantai pada daerah terakresi adalah 5,4 m/tahun. Abrasi terjadi sepanjang garis pantai penelitian di tempat yang belum dibangun groin. Laju abrasi selama tahun 2007 hingga tahun 2012 berkisar antara $0,4 \mathrm{~m} /$ thn hingga $5 \mathrm{~m} /$ tahun.

2. Dari hasil pengamatan menggunakan citra satelit yang bersumber dari Google Earth, tahun 2012- 2018. Pada saat setelah dibangun groin. Terjadi akresi di sepanjang lokasi pantai tempat penelitian. Pertambahan garis pantai mencapai $25 \mathrm{~m}$ dan laju akresi mencapai 4,2 meter/tahun. Pada daerah yang belum dibangun groin, terjadi abrasi akibat pengaruh berkurangnya pasokan sedimen karena telah ditangkap oleh groin yang berada pada sisi kirinya.

3. Berdasarkan simulasi Genesis 10 tahun kedepan dari tahun 2017, terjadi pergerakan sedimen yang bergerak dari kiri kekanan saat pengamat menghadap kelaut. Pola abrasi dan akresi sama dengan pola abrasi dan akresi yang terjadi sepanjang garis penelitan pada tahun 2012 hingga tahun 2018.

4. Pemasangan groin yang banyak di pantai lokasi penelitian efektif dalam memajukan garis pantai, pola yang sama dengan hasil running Genesis. Namun berdampak negatif pada daerah yang belum dibangun groin

5. Dalam simulasi Genesis, daerah yang belum dibangun groin (Pasie Jambak, Kel. Pasie Nan Tigo, kota Padang) terjadi abrasi sepanjang $445 \mathrm{~m}$ akibat pengaruh pemasangan groin pada daerah sebelumnya

\section{DAFTAR PUSTAKA}

CERC, Shore Protection Manual 1984. VOL I-IV, Washington DC

Dalrino, R.S, Elvi, 2015. Kajian Terhadap Unjuk Kerja Bangunan Pengaman Pantai Dengan Penerapan Simulasi Numerik One Line Model. Jurusan Teknik Sipil Politeknik Negeri Padang. Vol 10, Nomor 2,

Imran, M. 2016. Penentuan pola transport sediment dengan mike 21 (contoh Kasus pantai lampu satu kabupaten merauke papua). Jurnal Fakultas Teknik Universitas Hasanudin, Makasar.

Istijono, Bambang. 2013. Tinjauan Lingkungan Dan Penanggulangan Abrasi Pantai Padang, Sumatera Barat. Jurnal : Rekayasa Sipil. Vol. 9 No 2

Suhaemi dan Riandini, F. 2013.Dinamika garis pantai sanur bali akibat adanya struktur sejajar pantai Shoreline dynamic at sanur bali due to parallel structure. Jurnal teknik Hidraulik, Universitas Negeri Papua, Vol. 4 No. 1, Juni 2013: 79-90 